\title{
Prevalence of Botrytis spp. in Onion Seed Crops in the Columbia Basin of Washington
}

\author{
Lindsey J. du Toit and Mike L. Derie, Washington State University, Mount Vernon REU, Mount Vernon 98273; and \\ Gary Q. Pelter, Washington State University, Grant/Adams Counties, Ephrata 98823
}

\begin{abstract}
du Toit, L. J., Derie, M. L., and Pelter, G. Q. 2004. Prevalence of Botrytis spp. in onion seed crops in the Columbia Basin of Washington. Plant Dis. 88:1061-1068.

Of 12 onion seed lots harvested in the semi-arid Columbia Basin of Washington in 1999 or 2000, 8 were infected and 10 infested with Botrytis aclada at incidences of 1 to $10 \%$ and 2 to $26 \%$, respectively. Twenty to forty plants were sampled from each of nine direct-seeded, biennial seed crops in April, June, and July 2001 and assayed for Botrytis spp. Six direct-seeded crops were sampled in October and November 2001 and April, June, and July 2002. One bulb-to-seed crop was sampled in April, June, and July 2002. The incidence of B. aclada increased through each season, reaching $100 \%$ in most fields by July. Infections were primarily asymptomatic, with no apparent relationship between plant infection and infection of harvested seed. $B$, cinerea, $B$. squamosa, and $B$. porri were detected in 16,4 , and $4 \%$ of the fields, respectively, at lower incidences than B. aclada. Harvested seed from 15 of the fields were infected with B. aclada at $<1$ to $28 \%$. B, cinerea, B. porri, and B. squamosa were detected in three, three, and none of the harvested lots, respectively.
\end{abstract}

Additional keywords: Botrytis allii, Botrytis byssoidea, neck rot, Pacific Northwest, scape blight, seed production, umbel blight

In 2002, 16,000 acres of storage onion bulbs and 1,100 acres of nonstorage onion bulbs harvested in Washington represented farmgate values of $\$ 91.5$ million and $\$ 9.5$ million, respectively (United States Department of Agriculture National Agricultural Statistics Service [NASS]). The state ranks third in the United States for production of storage onion bulbs, with more than $50 \%$ exported to Pacific Rim countries (NASS). Moreover, approximately 800 acres of onion seed crops valued at $\$ 5.7$ million are grown in Washington annually (31). Despite the minor acreage of the seed crops, Washington exports about $50 \%$ of the onion seed produced and contributes up to $20 \%$ of the world supply of onion seed $(37,39)$. Dependence of the onion industry on export markets necessitates the production of high-quality, disease-free onion bulbs and pathogen-free seed in Washington.

Of the seven species of Botrytis associated with diseases of Allium crops (12), five have been associated with neck and bulb rots of onion. Although neck rot is associated most commonly with Botrytis allii Munn (17,19; Fig. 1), B. aclada Fre-

Corresponding author: L. du Toit

E-mail: dutoit@wsu.edu

Accepted for publication 15 June 2004.

Publication no. D-2004-0810-01R

(C) 2004 The American Phytopathological Society sen. was the original species associated with this disease (9). B. allii, B. byssoidea J. C. Walker, and B. squamosa J. C. Walker subsequently were described as the cause of sclerotial neck rot $(25,42)$, mycelial neck rot (42), and small sclerotial neck rot (26), respectively. These diseases are now known collectively as neck rot (24). $B$. cinerea Pers.:Fr. has infrequently caused a cosmetic bulb disease referred to as brown stain (3).

Until the recent taxonomic and nomenclatural clarification by Yohalem et al. (44) of the neck rotting species of Botrytis, $B$. aclada usually was considered synonymous with $B$. allii, while $B$. byssoidea was regarded by some as conspecific with $B$. aclada (17). The lack of distinction was due, in part, to limitations in differentiating Botrytis spp. using classical morphological and cultural methods $(32,33)$. Nonetheless, Owen et al. (26) demonstrated that B. byssoidea and $B$. aclada are valid species. Two subgroups (AI and AII) within $B$. aclada now can be distinguished based on chromosome number and conidial dimensions $(13,38)$. Polymerase chain reaction and internal transcribed spacer restriction fragment length polymorphisms (ITSRFLPs) have been used to demonstrate that $\mathrm{AI}$ and $\mathrm{AII}$ are distinct from $B$. byssoidea $(28,30)$. In fact, Nielsen and Yohalem (29) concluded that the larger-spored subgroup developed as a result of a hybridization event between a small-spored isolate of B. aclada and an isolate of $B$. byssoidea. Yohalem et al. (44) proposed that $B$. aclada be reserved for the smallspored subgroup (AI) and B. allii for the larger-spored subgroup (AII) of B. aclada.

Leaf blight of onion is associated primarily with $B$. squamosa, although $B$. cinerea can cause a mild foliar symptom (10). In onion seed crops, blighting and girdling of the scapes (seed stalks), and flower and umbel blight (Fig. 2) have been associated primarily with $B$. allii (usually not differentiated from $B$. aclada), as well as with $B$. squamosa, $B$. cinerea, and $B$. byssoidea $(1,5,8,11,15,19,27,34-36,43)$. $B$. aclada and $B$. allii can reduce plant stand, vigor, and bulb and seed yield and quality, and may result in infected seed lots $(4,17)$.

These fungi overwinter as sclerotia in cull piles, onion debris, and bulbs or on volunteers. Sclerotia may survive for more than 2 years in the soil and in cull piles $(2,20)$ to produce conidia that are dispersed by wind currents. Symptoms in bulb crops typically develop only after storage, sometimes resulting in severe losses (17).

Several studies have demonstrated that the incidence of neck rot in storage can be related directly to the incidence of infected onion seed from which the crop was grown, but that prevailing weather conditions can influence this relationship significantly $(21,22,40,41)$. Furthermore, Tylkowska and Dorna (41) demonstrated a stronger correlation of internally infected seed than infested (surface-contaminated) seed with seedling infection and neck rot of bulbs by $B$. allii. The significance of seedborne inoculum in development of neck rot is particularly controversial because of the latent nature of infection by these pathogens and the prevalence of alternative sources of inoculum (infested culled onion bulbs, volunteers, and debris) in most regions of onion production $(18,19)$. Lacy and Lorbeer (17) stated that most onion seed produced in the United States is grown in arid climates and, thus, is relatively free of the neck rot pathogens. However, there has been little research to determine the identity and prevalence of Botrytis spp. in the primary region of onion seed production in the United States, the semi-arid Pacific Northwest, which includes the Columbia Basin of central Washington, the Treasure Valley in southwestern Idaho and northeastern Oregon, and central Oregon. The objectives of this study were to (i) determine the prevalence of Botrytis spp. in onion seed lots produced in the semi-arid Columbia Basin, a 
100-by-100 km area within Adams, Franklin, and Grant Counties in central Washington, and (ii) examine the nature of infection of biennial onion seed crops by Botrytis spp. in this area. Preliminary results have been published $(6,7)$.

\section{MATERIALS AND METHODS}

Botrytis spp. on onion seed produced in central Washington in 1999 and 2000. As a preliminary determination of the prevalence of Botrytis spp. in onion seed lots produced in central Washington, 12 seed lots harvested from seed crops in this region in 1999 and 2000 were provided by seed companies to assay for Botrytis spp. using a selective agar medium referred to as Kritzman's agar (16; Table 1). Kritzman's agar was selected because of the advantages this medium provides over other media with respect to repeatable nutrient consistency, freedom from secondary contaminants, and ease of identifying Botrytis spp. (23). Initial seed assays were carried out in February and March 2001. Seed from each lot $(n=50)$ was rinsed under running deionized water for $60 \mathrm{~min}$, dried in a laminar flow hood on paper towels sterilized with $70 \%$ ethyl alcohol, and plated onto Kritzman's agar (20 seed per 10-cm-diameter petri plate). The seed were incubated at $24^{\circ} \mathrm{C}$ with $12 \mathrm{~h}$ of day and $12 \mathrm{~h}$ of night (cool white fluorescent light by day) for 14 days, and examined microscopically (up to $\times 100$ magnification) for development of Botrytis spp. approximately 4, 7, 10, and 14 days after plating. Cultures resembling Botrytis spp. were transferred to acidified potato dextrose agar (PDA; $39 \mathrm{~g}$ of Difco PDA [Becton, Dickinson, and Co., Sparks, MD] in 1 liter of deionized water, with six drops of $85 \%$ lactic acid added after the autoclaved medium has cooled to $50^{\circ} \mathrm{C}$ ) for species determination based on colony morphology, rate of colony growth, sporulation, and sclerotium characteristics $(10,32,33)$. No attempt was made to differentiate $B$. allii from B. aclada (44). B. aclada is used throughout this manuscript to represent either species unless stated otherwise. To differentiate surface contamination (henceforth referred to as infestation) from internal seed infection, 100 seed from each lot were surface sterilized in $0.5 \% \mathrm{NaOCl}$ for $60 \mathrm{~s}$, triple-rinsed in sterile deionized water, then air dried, plated, and examined as described for the nonsterilized seed samples. To assess the duration of survival of Botrytis spp. in onion seed, 100 seed from each of the 12 lots were assayed again in January and February 2003 using the protocols for infested and infected seed assays as described above. Means, standard errors, and $t$ tests were calculated with a $t$ test at $P<0.05$, indicating the mean incidence of infested or infected seed was significantly $>0$.

Botrytis spp. in onion seed crops in central Washington: 2001 survey. Nine onion seed fields (identified as fields A to I) were selected in early spring 2001 to survey for infection by Botrytis spp. (Table 2 ). The crops represented different onion seed companies and production practices (e.g., center pivot, solid-set, furrow, and drip irrigation; open pollinated and hybrid seed crops; and the full area of onion seed production in the Columbia Basin [i.e., Adams, Franklin, and Grant Counties]). This also is the primary area for production of storage onion bulbs in Washington (approximately 16,000 acres annually). As a result, the seed crops sampled were almost all located within 5 to $15 \mathrm{~km}$ of annual bulb crops or cull piles for at least part of the season. All nine crops were planted in July 2000 from stock seed (seed of the parent lines used to grow a seed crop), i.e., as direct-seeded seed crops. Information on the region or country in which each stock seed lot was produced was not provided for proprietary reasons. In early April 2001, prior to emergence of the scapes, 40 plants were collected from each crop by sampling in a W-shaped pattern. Each plant was placed in a plastic bag and stored in a cooler with ice for transport to a refrigerated storage facility (7 to $10^{\circ} \mathrm{C}$ ). The plants were kept in cold storage for 4 to 5 weeks, then each plant was washed under running tap water, cut lengthwise using a knife (sterilized with $70 \%$ ethanol between samples), and incubated on damp paper towels in a Sterilite plastic container $(24 \mathrm{~cm}$ wide by $37 \mathrm{~cm}$ long by $14 \mathrm{~cm}$ tall; Sterilite Corp., Townsend, MA) for 5 days. Each plant then was examined for Botrytis spp. using a dissecting microscope. Potential Botrytis isolates were transferred to acidified PDA for species determination.

The number of plants sampled from each field again in early June and late July 2001 was decreased to 20 because of the large size of individual plants. The plants were processed as described above. For the latter two sampling periods, plants were sampled down four or five rows/crop, because the height of the plants prevented sampling in a W-shaped pattern without causing considerable crop damage. In early June, most sampled plants had an immature umbel with a closed spathe. By late
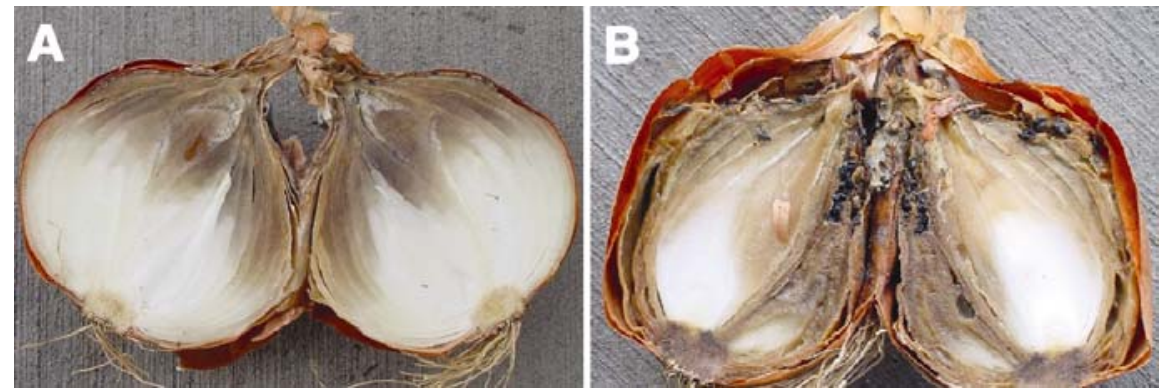

Fig. 1. Symptoms of onion neck rot caused by Botrytis aclada or B. allii. Sclerotia are present between the scales in the neck region of the bulb on the right. (Photo courtesy of M. I. Chilvers, Department of Plant Pathology, Washington State University).
July, the spathes were open and senescing, and a majority of the flowers had been pollinated. Sixteen bolted (flowering) volunteer onion plants growing approximately $1 \mathrm{~km}$ from field A were collected in July 2001 and assayed for Botrytis spp. to determine whether volunteer onion plants can serve as a source of inoculum of $B$. aclada. Samples $(n=400)$ of stock (if available from the seed company) and harvested seed from each of the nine seed crops were assayed for infection and infestation by Botrytis spp. as described above (Table 3).

Botrytis spp. in onion seed crops in central Washington: 2001-02 survey. The survey was repeated in the 2001-02 season with the addition of two sampling periods, late September and early November, to collect plants before and after hard fall frosts, respectively. Fall sampling was included in the second season to determine how early Botrytis spp. could be detected. Seven direct-seeded onion seed crops (fields A to G, planted in July or early August 2001) and one bulb-to-seed crop (field $\mathrm{H}$, for which the bulbs were transplanted in late March 2002) were included in the survey (Table 4). Field B was dropped from the survey because the crop was plowed under by the grower in March 2002. Forty plant samples were collected
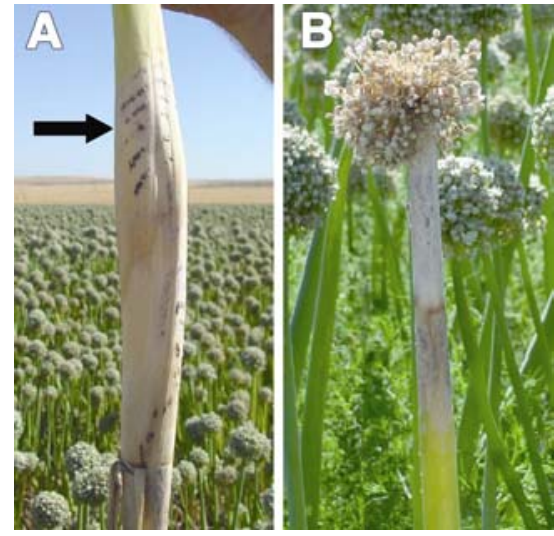

Fig. 2. Symptoms of scape blight (left) and scape and umbel blight (right) caused by Botrytis aclada (or B. allii) on plants sampled from an onion seed crop in central Washington in July 2001. Sclerotia form in concentric rings on the scape (arrow). 
from each direct-seeded crop in late September and again in early November 2001, and 20 plants were collected from each crop in early April, early June, and late July 2002. The samples were processed and assayed for infection by Botrytis spp. as described for the 2001 survey. In addition, to examine the potential relationship between symptomatic and asymptomatic infection in each crop at each sampling period, the presence of symptoms of neck rot, scape blight, and umbel blight was recorded for each plant sampled and for two adjacent plants on both sides, giving a total incidence of symptomatic plants/100 plants sampled. Samples of stock seed and harvested seed were assayed for infection as described for the 2001 survey. Surface (infestation) assays were not carried out on the harvested seed lots because of the prevalence of fast-growing fungi (primarily Aspergillus niger and Penicillium spp.) on the seed.

For both the 2001 and the 2001-02 surveys, means, standard errors, and $t$ tests were calculated to compare results among sampling periods, types of irrigation, hybrid versus open-pollinated crops, and stock and harvested seed assays. A probability of $P<0.05$ was used to determine if $t$ statistics were significant.

\section{RESULTS}

Botrytis spp. on onion seed produced in central Washington in 1999 and 2000. B. aclada was detected in onion seed pro- duced in Washington in 1998-99 and 1999-2000 (Table 1). No other species of Botrytis was detected on the 12 seed lots. In all, $8(67 \%)$ of the seed lots were infected with $B$. aclada at incidences ranging from 1 to $10 \%$, and $10(83 \%)$ were infested with $B$. aclada at incidences ranging from 2 to $26 \%$. For most lots, B. aclada was restricted to the seed coat. The mean \pm standard error of the incidence of infested and infected seed was $10.6 \pm 2.5$ and $1.9 \pm$ $0.8 \%$, respectively (Table 1 ). The mean incidence of infested seed was significantly lower $(P=0.0123)$ for lots harvested in $1999(3.3 \pm 2.1 \%)$ versus 2000 $(14.3 \pm 2.9)$. However, the mean incidence of infected seed was not significantly different $(P=0.1935)$ for lots harvested in

Table 1. Prevalence of Botrytis aclada in 12 onion seed lots harvested from seed crops grown in central Washington in 1998-99 and 1999-2000a

\begin{tabular}{|c|c|c|c|c|c|c|}
\hline \multirow[b]{3}{*}{ Seed $\operatorname{lot}^{\mathrm{c}}$} & \multirow[b]{3}{*}{ Year of harvest } & \multirow[b]{3}{*}{ Type of onion } & \multicolumn{4}{|c|}{ Incidence (\%) of seed with Botrytis acladab } \\
\hline & & & \multicolumn{2}{|c|}{2001} & \multicolumn{2}{|c|}{2003} \\
\hline & & & Infested & Infected & Infested & Infected \\
\hline $1 \mathrm{a}$ & 2000 & White & 20 & 10 & 1 & 1 \\
\hline $1 b$ & 1999 & White & 0 & 0 & 0 & 0 \\
\hline $2 \mathrm{a}$ & 2000 & White & 26 & 2 & 1 & 0 \\
\hline $2 \mathrm{~b}$ & 1999 & White & 0 & 0 & ND & 0 \\
\hline 3 & 2000 & White & 12 & 3 & 2 & 0 \\
\hline 4 & 2000 & Yellow & 13 & 2 & 1 & 0 \\
\hline $5 \mathrm{a}$ & 2000 & White & 19 & 1 & 0 & 0 \\
\hline $5 b$ & 1999 & White & 9 & 1 & 1 & 0 \\
\hline 6 & 2000 & Yellow & 18 & 0 & 2 & 0 \\
\hline 7 & 1999 & White & 4 & 3 & ND & 0 \\
\hline 8 & 2000 & Yellow & 2 & 1 & 0 & 0 \\
\hline 9 & 2000 & Yellow & 4 & 0 & ND & 0 \\
\hline Mean & $\ldots$ & $\ldots$ & 10.6 & 1.9 & 0.9 & 0.1 \\
\hline Standard error & $\ldots$ & $\ldots$ & 2.5 & 0.8 & 0.3 & 0.1 \\
\hline Probability $t>0^{\mathrm{d}}$ & $\ldots$ & $\ldots$ & 0.0015 & 0.0359 & 0.0092 & 0.3388 \\
\hline
\end{tabular}

a Isolates of B. aclada were not differentiated from B. allii (44).

${ }^{b}$ Infested: a sample of 50 (May and June 2001) or 100 (August 2003) seed per lot was rinsed in water, dried, plated onto Kritzman's agar medium (16), and examined microscopically at intervals for Botrytis spp. $(32,33)$. Infected: for each lot, 100 seed were surface-sterilized in $0.5 \% \mathrm{NaOCl}$, rinsed in water, then dried, plated, and examined microscopically as for the surface (infested) assay (August 2001 and February 2003). ND: the incidence of B. aclada could not be determined because of the prevalence of fast-growing fungi (primarily Aspergillus and Penicillium spp.).

${ }^{c}$ Seed lots with the same number were harvested from crops of the same cultivar grown in different years. Identities of cultivars are coded for anonymity of seed companies.

${ }^{\mathrm{d}}$ Probability the mean incidence of infected or infested seed is $>0$ based on a $t$ test.

Table 2. Onion seed crops surveyed in central Washington in 2001 for infection by Botrytis spp.

\begin{tabular}{|c|c|c|c|c|c|c|c|c|c|c|c|}
\hline \multirow[b]{3}{*}{ Seed crop } & \multirow[b]{3}{*}{ Irrigation $^{b}$} & \multirow[b]{3}{*}{$\mathbf{H}$ or $\mathbf{O P}^{\mathrm{c}}$} & \multicolumn{9}{|c|}{ Incidence $(\%)$ of plants infected ${ }^{a}$} \\
\hline & & & \multicolumn{3}{|c|}{ B. aclada } & \multicolumn{3}{|c|}{ B. cinerea } & \multicolumn{3}{|c|}{ B. squamosa } \\
\hline & & & April & June & July & April & June & July & April & June & July \\
\hline A & Wheel-line & $\mathrm{H}$ & 30 & 75 & 100 & 5 & 5 & 20 & 0 & 0 & 0 \\
\hline B & Furrow & $\mathrm{OP}$ & 30 & 100 & 100 & 10 & 10 & 0 & 0 & 0 & 0 \\
\hline $\mathrm{C}$ & Drip & $\mathrm{H}$ & 63 & 100 & 100 & 40 & 60 & 25 & 8 & 15 & 0 \\
\hline $\mathrm{D}$ & Center pivot & $\mathrm{H}$ & 95 & 100 & 100 & 25 & 10 & 5 & 25 & 0 & 5 \\
\hline E & Furrow & OP & 50 & 100 & 100 & 10 & 5 & 0 & 0 & 0 & 0 \\
\hline $\mathrm{F}$ & Furrow & $\mathrm{OP}$ & 30 & 90 & 100 & 3 & 15 & 40 & 0 & 0 & 0 \\
\hline G & Center pivot & OP & 18 & 70 & 95 & 5 & 75 & 100 & 0 & 5 & 10 \\
\hline $\mathrm{H}$ & Center pivot & $\mathrm{H}$ & 45 & 100 & 100 & 0 & 5 & 10 & 0 & 0 & 5 \\
\hline I & Furrow & $\mathrm{OP}$ & 38 & 100 & 100 & 0 & 0 & 5 & 0 & 0 & 0 \\
\hline Mean & $\ldots$ & $\ldots$ & 44.3 & 92.8 & 99.4 & 10.9 & 20.6 & 22.8 & 3.7 & 2.2 & 2.2 \\
\hline Standard error & $\ldots$ & $\ldots$ & 7.7 & 4.0 & 0.6 & 4.4 & 9.1 & 10.6 & 2.8 & 1.7 & 1.2 \\
\hline Prob. $t>0^{\mathrm{d}}$ & $\ldots$ & $\ldots$ & 0.0004 & $<0.0001$ & $<0.0001$ & 0.0397 & 0.0532 & 0.0641 & 0.2280 & 0.2249 & 0.1038 \\
\hline
\end{tabular}

${ }^{\text {a }}$ Forty plants were sampled in a W-shaped pattern from each crop in early April 2001, and 20 plants were collected randomly from each crop in early June and again in late July 2001. Plants were placed in cold storage for 4 to 5 weeks, washed under tap water, incubated in a moist chamber for 5 days, and examined microscopically for Botrytis spp. (32,33). Isolates of B. aclada were not differentiated from B. allii (44).

${ }^{b}$ Type of irrigation system under which each crop was grown. Field C was grown using solid-set irrigation in the fall of 2000 and drip irrigation in the spring and summer of 2001.

${ }^{\mathrm{c}} \mathrm{H}=$ hybrid, and $\mathrm{OP}=$ open pollinated.

d Probability the mean incidence of plants infected is $>0$ based on a $t$ test. 
$1999(1.0 \pm 0.7 \%)$ versus $2000(2.4 \pm$ $1.1 \%)$. Higher incidences of infection and infestation were detected on seed of the same cultivar grown in 2000 versus 1999 (lots $1 \mathrm{a}$ versus $1 \mathrm{~b}, 2 \mathrm{a}$ versus $2 \mathrm{~b}$, and $5 \mathrm{a}$ versus $5 \mathrm{~b}$; Table 1 ). The mean incidences of infested and infected seed of yellow cultivars $(9.3 \pm 3.8$ and $0.8 \pm 0.5 \%$, respectively) were not significantly different from those of white cultivars (11.3 \pm 3.4 and $2.5 \pm 1.1 \%$, respectively). Seed lots $2 \mathrm{~b}$, 7 , and 9 were heavily infested with fastgrowing fungi (primarily $A$. niger) when assayed in 2003, which prevented the detection of B. aclada.

Botrytis spp. in onion seed crops in central Washington: 2001 survey. The survey of nine onion seed fields from April to July of 2001 showed B. aclada to be ubiquitous in the Columbia Basin of Washington (Table 2). The incidence of plants infected with $B$. aclada ranged from 18 to $100 \%$ in individual crops, with a mean incidence of $44 \pm 8,93 \pm 4$, and $99 \pm 1 \%$ in early April, early June, and late July 2001, respectively. However, almost all plants were asymptomatic at the time of sampling, and only showed signs of infection (mycelial growth and sporulation) after 4 to 5 weeks of cold storage followed by incubation in a moist chamber for 5 days. Of the 180 plants sampled across all nine crops in June 2001, latent infections by $B$. aclada were observed on 89,86 , and $48 \%$ of the bulbs, scapes, and umbels, respectively. The fungus was not observed on immature umbels with unopened spathes, and was observed primarily on the membranous spathe of open umbels. Flowers had not opened by this sampling period. Just prior to harvest (late July), only one crop (field G) was $<100 \%$ infected. Most plants showed extensive latent infection and colonization by $B$. aclada, with mycelial growth and sporulation observed on 25 to $70 \%$ of the surface area of each plant after incubation. Of the 180 plants sampled across all nine crops in July, latent infections by $B$. aclada were observed on 89,97 , and $97 \%$ of the bulbs, scapes, and umbels, respectively. Umbel infection was more extensive compared with samples collected in early June, and often appeared to have originated from the senescing spathe attached at the base of the umbel.

The incidence of plants infected with $B$. cinerea ranged from 0 to $100 \%$ in 2001 ,

Table 3. Incidence of Botrytis spp. on stock seed and harvested seed of nine onion seed crops grown in central Washington in 2000-01

\begin{tabular}{|c|c|c|c|c|c|c|c|c|}
\hline \multirow[b]{3}{*}{ Seed crop } & \multicolumn{2}{|c|}{ Incidence (\%) of stock seed ${ }^{b}$} & \multicolumn{6}{|c|}{ Incidence $(\%)$ of harvested seed } \\
\hline & \multirow{2}{*}{$\begin{array}{c}\text { Infected } \\
\text { B. aclada }\end{array}$} & \multirow{2}{*}{$\begin{array}{c}\text { Infested } \\
\text { B. aclada }\end{array}$} & \multicolumn{3}{|c|}{ Infected } & \multicolumn{3}{|c|}{ Infested } \\
\hline & & & B. aclada & B. cinerea & B. squamosa & B. aclada & B. cinerea & B. squamosa \\
\hline A & 0.25 & 7.25 & 1.25 & 0.00 & 0.00 & 7.50 & 0.00 & 0.00 \\
\hline B & NA & NA & 4.75 & 0.00 & 0.00 & ND & ND & ND \\
\hline $\mathrm{C}$ & 0.00 & 0.00 & 1.25 & 0.00 & 0.00 & 17.50 & 0.00 & 0.00 \\
\hline D & 0.00 & 0.00 & 1.75 & 0.50 & 0.00 & 15.25 & 2.25 & 0.00 \\
\hline $\mathrm{E}$ & NA & NA & 6.50 & 0.00 & 0.00 & 0.75 & 0.00 & 0.00 \\
\hline $\mathrm{F}$ & NA & NA & 7.00 & 0.25 & 0.00 & 19.00 & 1.25 & 0.00 \\
\hline G & NA & NA & 1.75 & 1.25 & 0.00 & 12.38 & 1.13 & 0.00 \\
\hline $\mathrm{H}$ & NA & NA & 0.25 & 0.00 & 0.00 & 1.50 & 1.00 & 0.00 \\
\hline I & NA & NA & 3.50 & 0.00 & 0.00 & ND & ND & ND \\
\hline Mean & 0.08 & 2.42 & 3.11 & 0.22 & 0.00 & 10.55 & 0.80 & 0.00 \\
\hline Standard error & 0.08 & 2.42 & 0.82 & 0.14 & 0.00 & 2.81 & 0.32 & 0.00 \\
\hline Probability $t>0^{c}$ & 0.4226 & 0.4226 & 0.0052 & 0.1536 & $\ldots$ & 0.0095 & 0.0470 & $\ldots$ \\
\hline
\end{tabular}

a Infected: 400 seed per lot were surface-sterilized in $0.5 \% \mathrm{NaOCl}$, rinsed in water, dried, plated onto Kritzman's agar medium (16), and examined microscopically at 3- to 4-day intervals for development of Botrytis spp. (32,33). Isolates of B. aclada were not differentiated from isolates of B. allii (44). Infested: 400 seed per lot were rinsed in water, then dried, plated and examined microscopically as for the internal (infected) assay. NA: seed not available from the seed company. ND: incidence of infested seed could not be determined because of the presence of fast-growing fungi, primarily Aspergillus niger and Penicillium spp.

b Stock seed is the seed of the parent lines used to plant a seed crop. Only seed of the female parent was available to assay for the hybrid seed crops A, C, and D.

${ }^{\mathrm{c}}$ Probability the mean incidence of seed infected or infested is $>0$ based on a $t$ test.

Table 4. Onion seed crops surveyed in central Washington in 2001-02 for infection by Botrytis aclada

\begin{tabular}{|c|c|c|c|c|c|c|c|c|c|c|c|c|}
\hline \multirow[b]{3}{*}{ Seed crop ${ }^{c}$} & \multirow[b]{3}{*}{ Irrigation $^{\mathbf{d}}$} & \multirow[b]{3}{*}{ H or OPe } & \multicolumn{10}{|c|}{ Incidence (\%) of plants infected with $B$. aclada } \\
\hline & & & \multicolumn{5}{|c|}{ Plants sampled $^{\mathrm{a}}$} & \multicolumn{5}{|c|}{ Symptomatic infection in the field ${ }^{b}$} \\
\hline & & & Sep 01 & Nov 01 & Apr 02 & Jun 02 & Jul 02 & Sep 01 & Nov 01 & Apr 02 & Jun 02 & Jul 02 \\
\hline A & Solid-set & $\mathrm{H}$ & 5 & 5 & 15 & 100 & 100 & 0 & 0 & 0 & 0 & 7 \\
\hline B & Solid-set & $\mathrm{H}$ & 3 & 0 & $\ldots$ & $\ldots$ & $\ldots$ & 0 & 0 & $\ldots$ & $\ldots$ & $\ldots$ \\
\hline $\mathrm{C}$ & Furrow & $\mathrm{H}$ & 15 & 3 & 70 & 100 & 100 & 0 & 0 & 0 & 0 & 16 \\
\hline $\mathrm{D}$ & Furrow & $\mathrm{H}$ & 8 & 10 & 95 & 100 & 100 & 0 & 0 & 2 & 5 & 10 \\
\hline $\mathrm{E}$ & Furrow & $\mathrm{OP}$ & 63 & 0 & 70 & 100 & 100 & 0 & 0 & 0 & 2 & 10 \\
\hline $\mathrm{F}$ & Furrow & $\mathrm{OP}$ & 8 & 3 & 25 & 100 & 100 & 0 & 0 & 1 & 6 & 7 \\
\hline G & Furrow & $\mathrm{OP}$ & 18 & 3 & 30 & 95 & 100 & 0 & 0 & 0 & 2 & 4 \\
\hline $\mathrm{H}^{\mathrm{f}}$ & Center pivot & $\mathrm{H}$ & $\ldots$ & $\ldots$ & 65 & 90 & 100 & 0 & 0 & 0 & 0 & 17 \\
\hline Mean & $\ldots$ & $\ldots$ & 17.1 & 3.4 & 52.9 & 97.9 & 100.0 & 0.0 & 0.0 & 0.4 & 2.1 & 10.1 \\
\hline SE & $\ldots$ & $\ldots$ & 7.9 & 1.2 & 11.2 & 1.5 & 0.0 & 0.0 & 0.0 & 0.3 & 0.9 & 1.8 \\
\hline Prob. $t>0$ & $\ldots$ & $\ldots$ & 0.0731 & 0.0375 & 0.0032 & $<0.0001$ & $<0.0001$ & $\ldots$ & $\ldots$ & 0.1996 & 0.0622 & 0.0014 \\
\hline
\end{tabular}

${ }^{\text {a }}$ Forty plants were sampled from each crop in late September (Sep) and early November (Nov) 2001, and 20 plants were collected randomly from each crop in early April (Apr), early June (Jun), and late July (Jul) 2002 (except for the crop in field B, which was plowed in March 2002). Plants were placed in cold storage for 4 to 5 weeks, washed, incubated in a moist chamber for 5 days, and examined microscopically for Botrytis spp. (32,33). Isolates of B. aclada were not differentiated from $B$. allii (44).

b Visual assessment of 200 plants/crop for the 2001 samples and 100 plants/crop for the 2002 samples (the plant sampled as well as two plants on each side) for symptoms of neck rot, bulb rot, scape blight, and umbel blight.

c $\mathrm{SE}=$ standard error; Prob. $=$ probability the mean incidence of infected (symptomatic or asymptomatic) plants is $>0$ based on a $t$ test.

d Type of irrigation system under which each crop was grown.

${ }^{\mathrm{e}} \mathrm{H}=$ hybrid, and $\mathrm{OP}=$ open pollinated crop.

f Bulb-to-seed crop planted in March 2002 using vernalized bulbs shipped from the Central Valley of California. All other crops were direct-seeded in July 2001. 
and generally was lower than the incidence of plants infected with $B$. aclada. The incidence increased slightly through the season with a mean of $11 \pm 4,21 \pm 9$, and 23 $\pm 11 \%$ infected plants in April, June, and July, respectively. B. squamosa was detected in four of the nine seed crops surveyed in 2001, at incidences ranging from 5 to $25 \%$ in individual crops. The incidence of $B$. porri in crops sampled in 2001 was reported by du Toit et al. (6).

Based on the number of plants collected at each sampling period, the incidence of plants infected with $B$. aclada was significantly greater than 0 at all sampling periods in 2001 (Table 2). However, the incidence of plants infected with $B$. cinerea was significantly greater than 0 only in April 2002, and the incidence of plants infected with $B$. squamosa was not significant at any sampling period. There were no significant differences in incidence of $\mathrm{Bo}$ trytis spp. between overhead (wheel line and center pivot) and non-overhead (furrow and drip) types of irrigation, regardless of the sampling period. Similarly, there were no significant differences in incidence of Botrytis spp. between hybrid and open-pollinated crops.

Stock seed samples were assayed for the female parents of three of the nine seed crops surveyed in 2001 (Table 3). Stock seed samples were not provided by seed companies for the male parents of these crops or for the parent lines of the other six crops. Only one stock seed lot (field A) was infected and infested with $B$. aclada, at incidences of 0.25 and $7.25 \%$, respectively. However, B. aclada subsequently was detected in the harvested seed of all nine seed crops, at incidences ranging from 0.25 to $7.00 \%$ infection (mean of $3.11 \pm 0.82 \%$ ), and 0.75 to $19.00 \%$ infestation (mean of $10.55 \pm 2.81 \%$ ) (Table 3 ). Assays for infested seed harvested from fields B and I could not be completed because of contamination by fast-growing nontarget fungi, primarily Aspergillus and Penicillium spp. The correlations between incidence of stock versus harvested seed infected or infested with $B$. aclada were not significant (data not shown), although the number of stock seed lots assayed was limited. Similarly, correlations between incidence of harvested seed infected or infested with $B$. aclada and incidence of plants infected with B. aclada in April, June, and July 2001 were not significant (data not shown).

$B$. cinerea was detected in seed harvested from four fields (fields D, F, G, and $\mathrm{H})$ at incidences ranging from 0.25 to $1.25 \%$ infection and 1.00 to $2.25 \%$ infestation. $B$. squamosa was not found in any of the harvested or stock seed. The incidence of $B$. porri detected in harvested seed was reported by du Toit et al. (6). The incidence of $B$. cinerea on plants in June and July 2001 correlated significantly with the incidence of harvested seed infected with
B. cinerea $(r=0.667$ at $P=0.0497$ and $r=$ 0.854 at $P=0.0034$, respectively). There were no significant correlations between incidences of plants and seed infected with B. squamosa and B. porri in 2001.

Of the 40 plants collected from field $\mathrm{G}$ (an open pollinated crop under center pivot irrigation) in April 2001, none sampled from the western half of the field was infected with Botrytis spp. However, 7 of 20 plants $(35 \%)$ sampled from the eastern half were infected with B. aclada (with $95 \%$ binomial confidence limits of 3 to $67 \%$ ). A single plant $(5 \%)$ was infected with $B$. cinerea. By June 2001, 5 of 10 plants (50\%, with confidence limits of 3 to $97 \%$ for $n=10$ plants) sampled from the western half of the field had minor latent infections by $B$. aclada observed in a few small areas of the neck or scape after cold storage and incubation. In contrast, all 10 plants $(100 \%)$ sampled from the eastern half were colonized extensively by $B$. aclada after incubation. In June, the western half of the field had a high population of weeds while the eastern half was almost weed free. Enquiries with the grower and seed company personnel revealed that the lack of weed control in the western half of the field resulted from failure of the injection system midway through chemigation of herbicides early in April. The incidence (and 95\% binomial confidence limits) of seed infested and infected with $B$. aclada from the western (weedy) half of the crop was $4.75 \%$ (1.56 to $7.94 \%)$ and $1.00 \%$ (0 to $3.11 \%$, respectively. In contrast, $20.00 \%$ (14.00 to $26.00 \%$ ) and $2.50 \%$ (0 to $11.62 \%)$ of the seed from the eastern (weed-free) half of the crop were infested and infected with $B$. aclada, respectively. The incidence of seed infested and infected with $B$. cinerea in the weedy half of the crop was $1.50 \%$ (0 to $3.32 \%$ ) and $0.50 \%$ (0 to $2.04 \%)$, respectively, compared with 0.75 (0 to $2.04 \%$ ) and $2.00 \%$ ( 0 to $2.48 \%$ ) in the weed-free half, respectively.

B. aclada was detected on 14 of the 16 volunteer plants $(87.5 \%)$ sampled approximately $1.0 \mathrm{~km}$ from field A in July 2001, with latent infection detected on the bulb or neck, scape, and umbel of 12 of 16 (75\%), 13 of 14 (93\%), and 3 of $8(38 \%)$ plants, respectively.

Botrytis spp. in onion seed crops in central Washington: 2001-02 survey. For the 2001-02 survey, B. aclada was detected in all seven crops surveyed within 2 months of planting (late September 2001), at a mean incidence of $17 \pm 8 \%$ (47 of 280 plants sampled across seven crops; Table 4). The incidence of infected plants was $<20 \%$ for all crops except field E $(63 \%)$, plants were asymptomatic at the time of sampling, and the extent of colonization observed on individual plants after storage and processing was limited to a few conidiophores (Table 4). By November 2001 (after the onset of fall frosts), the incidence of B. aclada dropped to a mean of $3 \pm 1 \%$
(9 of 280 plants sampled), with only latent infections and limited colonization by $B$. aclada. By April 2002, the mean incidence of infected plants increased to $53 \pm 11 \%$ (74 of 140 plants), with a range of incidence from 15 to $95 \%$ in individual crops. Nonetheless, most of this infection was latent because symptoms were observed in only two crops, those in fields D and F, at incidences of 1 and $2 \%$, respectively (Table 4). The incidence of plants infected with B. aclada in the seven crops (six direct-seeded and one bulb-to-seed crop) remaining after the crop in field $\mathrm{B}$ was plowed, increased to a mean disease incidence of $98 \pm 2$ and $100 \pm 0 \%$ for plants sampled in early June and late July 2002, respectively (Table 4). For the latter two sampling periods, mycelial growth and sporulation of $B$. aclada was extensive on plants after cold storage for 4 to 5 weeks followed by incubation in a moist chamber. Of the 180 plants sampled in June 2002, latent infections by $B$. aclada were observed on 88,87 , and $83 \%$ of the bulbs, scapes, and umbels, respectively. By late July 2002, the total incidence of latent infection by $B$. aclada was 85,94 , and $99 \%$ on the bulbs, scapes, and umbels, respectively. In contrast, the incidence of plants showing symptoms of bulb rot, neck rot, scape blight, or umbel blight in the field at the time of sampling averaged $2 \pm$ $1 \%$ in early June, with symptoms observed in four of the seven crops at incidences ranging from $2 \%$ (fields $\mathrm{E}$ and $\mathrm{G}$ ) to $6 \%$ (field F). By late July 2002, the mean incidence of symptomatic plants was $10 \pm 2 \%$, with symptoms observed in all seven crops at incidences ranging from $4 \%$ (field $\mathrm{G}$ ) to $17 \%$ (field $\mathrm{H}$ ) (Table 4). A majority of the symptomatic infection was observed in the bulbs and necks. $B$. cinerea was detected at similar incidences to the 2001 survey; $B$. porri was detected in only one crop, field $\mathrm{G}$, on $5 \%$ of the plants sampled in late July 2002 ; and B. squamosa was not detected in the 2001-02 survey.

Based on the number of plants collected at each sampling period, the incidence of plants infected with $B$. aclada was significantly greater than 0 for all sampling periods except September 2001 (Table 4). The incidence of symptomatic plants was significantly greater than 0 only in July 2002 . There were no significant differences in incidence of symptomatic or asymptomatic infection between crops with overhead (solid-set or center pivot) versus non-overhead (furrow) types of irrigation. Similarly, there were no significant differences in incidence of symptomatic or asymptomatic infection between hybrid and open pollinated crops (data not shown).

Stock seed was provided by seed companies for four of the seven crops surveyed in 2001-02 (Table 5). Two of the six stock seed lots were infected with B. aclada (i.e., fields $\mathrm{E}$ and $\mathrm{G}$ at 1.50 and $3.00 \%$, respectively), and four were infested with $B$. 
aclada (at 0.75 to $6.75 \%$ ). B. aclada was present in six of seven harvested seed lots at incidences ranging from 0.25 to $28.25 \%$ infection (mean of $6.46 \pm 3.74 \%$; Table 5). This fungus was not detected in harvested seed from field $\mathrm{H}$, the only bulb-to-seed crop in the survey (grown under center pivot irrigation). As with the 2001 survey, there was no apparent relationship between the incidence of Botrytis spp. detected in harvested seed and the incidence of plants infected symptomatically or asymptomatically with $B$. aclada prior to harvest, or with the incidence of $B$. aclada detected on stock seed (Tables 4 and 5). Similarly, there was no difference in incidence of infected plants or infected seed lots among fields with different types of irrigation. Plants sampled from fields $\mathrm{C}$ and $\mathrm{H}$ had the highest incidence of symptomatic infection in July 2002, 16 and $17 \%$, but $B$. aclada was detected in 6.00 and $0 \%$ of the harvested seed from these two crops, respectively. B. cinerea and $B$. squamosa were not detected in harvested seed lots, but $0.25 \%$ of the harvested seed from field $\mathrm{F}$ was infected with $B$. porri (Table 5).

\section{DISCUSSION}

Based on these surveys, B. aclada is ubiquitous in the semi-arid Columbia Basin of central Washington. B. aclada, undifferentiated from $B$. allii sensu Yohalem et al. (44), was detected in every onion seed crop surveyed regardless of production practices, and increased in prevalence through the biennial cropping season to an incidence of almost $100 \%$ just prior to harvest. Most infections detected were latent, similar to the latent nature of infection of onion bulb crops by this pathogen. Incubation of plants in cold storage for 4 to 5 weeks followed by incubation in a moist chamber for 5 days proved effective for detecting latent infection by Botrytis spp. on plants sampled at any stage of maturity.

Latency of $B$. aclada infections in onion bulb and seed crops complicates efforts to manage the pathogen through scouting and protective fungicide applications. Observations of umbel and flower infection in early June and late July illustrated that umbels and, thus, developing seed were infected primarily after the spathe had opened and begun to senesce and the florets were open. These observations concur with those of Ramsey and Lorbeer (35), who demonstrated that open onion florets are more susceptible to infection by $B$. aclada, B. cinerea, and $B$. squamosa than closed florets. Considering the ubiquitous nature of B. aclada in the Columbia Basin, timing the application of protective fungicides to coincide with the developing umbel in early to mid-summer may prove more effective at controlling infection of the developing seed than fall or spring applications. Seed growers in the Columbia Basin typically apply chlorothalonil or iprodione for control of scape and umbel blight (14). The prevalence of latent $B$. aclada infections in all seed crops surveyed, many of which received fungicide applications in the fall and spring, suggests limited efficacy of these applications at preventing infection by $B$. aclada. Research is needed to determine the optimum timing of fungicide applications relative to umbel maturity.

The prevalence of B. aclada in the Columbia Basin contrasts with previous reports by Maude and Presly $(21,22)$ in the United Kingdom, who indicated that $B$. allii (not differentiated from $B$. aclada) was not ubiquitous in that country and only occurred where crops were grown from infected seed. In environments where
B. aclada is prevalent, seedborne inoculum may be less important in spread of neck rot than infested debris and culled onion bulbs. Linfield et al. (18) found that inoculating onion plants during the growing season led to greater levels of neck rot than did planting infested seed.

The limited availability of stock seed samples for the survey in central Washington restricted the ability to determine the role of infected stock seed as a source of inoculum for onion seed crops in central Washington. Nonetheless, based on the lack of any obvious relationship between stock seed infection or infestation, the incidence of asymptomatic or symptomatic infection on plants during the cropping season, and the incidence of infection in harvested seed, onion seed produced in the semi-arid Columbia Basin may become infected primarily from airborne inoculum deposited onto the umbels, as opposed to systemic movement of $B$. aclada from stock seed into developing seedlings or from the bulb and scape into the umbel. The presence of extensive onion bulb acreage in the same area of onion seed production in central Washington, together with abundant sources of inoculum from volunteers, cull piles, and debris, results in ample opportunity for survival and dissemination of B. aclada between biennial seed crops and annual bulb crops.

The environment in which onion bulb and seed crops are grown may influence the predominant species of Botrytis infecting these crops and the nature of infection by these species. In the Columbia Basin, the minimum, average, and maximum temperatures were 13,22 , and $30^{\circ} \mathrm{C}$ in July 2001 , and 14,23 , and $32^{\circ} \mathrm{C}$ in July 2002 , respectively. In addition, no precipitation occurred in the Columbia Basin during July of either year, although seed crops

Table 5. Incidence of Botrytis spp. on stock seed and harvested seed of eight onion seed crops grown in central Washington in 2001-02

\begin{tabular}{|c|c|c|c|c|c|c|}
\hline \multirow[b]{3}{*}{ Seed crop } & \multicolumn{2}{|c|}{ Incidence $(\%)$ of stock seed ${ }^{b}$} & \multicolumn{4}{|c|}{ Incidence $(\%)$ of harvested seed } \\
\hline & \multirow{2}{*}{$\begin{array}{c}\text { Infected } \\
\text { B. aclada }\end{array}$} & \multirow{2}{*}{$\frac{\text { Infested }}{\text { B. aclada }}$} & \multicolumn{4}{|c|}{ Infected } \\
\hline & & & B. aclada & B. cinerea & B. squamosa & B. porri \\
\hline \multirow[t]{2}{*}{ A } & $0.00 \mathrm{~F}$ & $0.75 \mathrm{~F}$ & 0.25 & 0.00 & 0.00 & 0.00 \\
\hline & $0.00 \mathrm{M}$ & $0.75 \mathrm{M}$ & & & - & $\ldots$ \\
\hline \multirow[t]{2}{*}{ B } & $0.00 \mathrm{~F}$ & NA & NA & NA & NA & NA \\
\hline & $0.00 \mathrm{M}$ & NA & & & & \\
\hline $\mathrm{C}$ & NA & NA & 6.00 & 0.00 & 0.00 & 0.00 \\
\hline $\mathrm{D}$ & NA & NA & 5.50 & 0.00 & 0.00 & 0.00 \\
\hline E & 1.50 & 0.75 & 28.25 & 0.00 & 0.00 & 0.00 \\
\hline $\mathrm{F}$ & NA & NA & 3.75 & 0.00 & 0.00 & 0.25 \\
\hline G & 3.00 & 6.75 & 1.50 & 0.00 & 0.00 & 0.00 \\
\hline $\mathrm{H}$ & NA & NA & 0.00 & 0.00 & 0.00 & 0.00 \\
\hline Mean & 0.75 & 2.25 & 6.46 & 0.00 & 0.00 & 0.04 \\
\hline Standard error & 0.51 & 1.50 & 3.74 & 0.00 & 0.00 & 0.04 \\
\hline Probability $t>0^{c}$ & 0.2152 & 0.3029 & 0.1348 & $\ldots$ & $\ldots$ & 0.3559 \\
\hline
\end{tabular}

a Infected: a sample of 400 seed/lot was surface-sterilized in $0.5 \% \mathrm{NaOCl}$, rinsed in water, dried, plated onto Kritzman's agar medium (16), and examined microscopically at 3- to 4-day intervals for Botrytis spp. (32,33). Isolates of B. aclada were not differentiated from isolates of $B$. allii (44). Infested: a sample of 400 seed/lot was rinsed under running water, dried, plated onto Kritzman's agar medium and examined microscopically as described for the infected assay. Surface (infested) assays were not carried out on harvested seed in 2002 because of the high incidence of fast-growing fungi (primarily Aspergillus niger and Penicillium spp.). NA: seed not available from the seed company. Crop B was plowed in spring 2002, so harvested seed was not available.

${ }^{\mathrm{b}}$ Stock seed $=$ seed of the parent lines used to plant a seed crop. $\mathrm{F}$ and $\mathrm{M}=$ stock seed of the female and male parents, respectively, of a hybrid seed crop.

${ }^{\mathrm{c}}$ Probability the mean incidence of infected or infested seed is $>0$ based on a $t$ test. 
were irrigated through mid-July. The low incidence of $B$. squamosa relative to $B$. aclada in seed crops in central Washington and the prevalence of latent infections in this semi-arid area probably reflect the more optimal environmental conditions for B. aclada than B. squamosa in the Columbia Basin (36).

Results of the Washington survey differ from the results of a survey of onion seed crops carried out in Orange County, New York, from 1976 to 1981 (34,35). In the latter survey, the natural occurrence of umbel blight was positively correlated with total rainfall in July, and was described as being caused by a pathogen complex of $B$. allii, B. cinerea, and B. squamosa, of which the relative importance of each species varied among seasons. An epidemic of scape and umbel blight occurred in 1976 when rainy conditions prevailed during the flowering period in July and the average July temperature was $2^{\circ} \mathrm{C}$ cooler than during 1977 to 1981. B. squamosa was isolated more frequently, and $B$. allii less frequently, from the florets in 1976 compared with 1977 to 1981. All species caused symptomatic infections and were not isolated from asymptomatic tissue below the girdled areas of the scapes, suggesting a lack of latent infections.

$B$. cinerea was detected in most seed crops surveyed in the Columbia Basin in 2001 and 2002, but at a lower incidence than B. aclada in plant samples and in only three of the harvested seed lots assayed. The prevalence of this species as a secondary invader of diseased plant tissues is well documented and appears to reflect the variable incidence detected in this survey. $B$. byssoidea was not detected in the seed crops surveyed in Washington. However, this study demonstrated the natural occurrence of $B$. porri on onion plants and seed in two seasons. du Toit et al. (6) published the first report of this species occurring naturally on onion from the first year of the survey. $B$. porri is a pathogen of garlic and leek (4). The significance of this species as a pathogen of onion and the source of infection of four seed crops remain to be clarified, given the very limited acreage of garlic and leek in the Columbia Basin.

Although B. aclada was detected in a majority of the seed lots assayed, the range in incidence of infected and infested seed was similar to incidences reported in previous studies $(19,21-23,41)$. The inability to detect the pathogen in harvested seed from one of seven crops surveyed in 200102 indicates that Botrytis-free onion seed can be produced in the semi-arid Pacific Northwest despite the ubiquitous nature of B. aclada. Differences in levels of seedborne infection in lots of the same cultivar produced in different years may reflect differences in environmental conditions among years or loss in viability of $B$. aclada in onion seed with storage. Maude and Presly (21) found that B. allii re- mained viable for 3.5 years on onion seed stored at $10^{\circ} \mathrm{C}$ and $50 \%$ relative humidity. However, very little $B$. aclada remained viable in most onion seed lots assayed 3 years after harvest in central Washington. The results may reflect the occurrence of more favorable conditions for infection by B. aclada in 2000 compared with 1999 , but the incidence of viable $B$. aclada detected in onion seed may have decreased with storage. The duration of survival of $B$. aclada in onion seed may vary depending on the degree of infection versus infestation.

Differentiating between infected versus infested seed may provide a more accurate indication of the risk of seed transmission than detecting infestation alone. Tylkowska and Dorna (41) demonstrated a stronger correlation of seedling and bulb infection with the incidence of seed infected versus infested by $B$. allii. However, the limited number of stock seed lots available in the Washington surveys confounded the ability to evaluate seed transmission from infested versus infected seed in this semi-arid area of onion seed production.

The higher incidence of latent infection by $B$. aclada detected in plants and seed from the section of field $\mathrm{G}$ with good weed control compared with the weed-infested section of this field in 2001 suggests that some herbicides or adjuvants may predispose onion plants to infection by Botrytis spp. Herbicides (e.g., bromoxynil, fluazifop-butyl, oxyfluorfen, and pendimethalin) are used intensively in onion seed production in the Columbia Basin because of the limited canopy produced by these crops, the potential for significant losses from weed competition, and quality concerns if harvested seed lots are contaminated with weed seed (14). Some herbicides may disrupt or reduce the integrity of the protective waxy cuticle, predisposing onion leaves and scapes to infection. Research is needed to clarify the potential influence of herbicides on susceptibility of onion bulb and seed crops to infection by Botrytis spp.

Using the Apol digest as described by Nielsen et al. (28), preliminary molecular analyses of isolates of $B$. aclada collected during this survey indicate that both $B$. aclada and $B$. allii are present in central Washington (data not shown). Central Washington serves as a "melting pot" for populations of Botrytis spp. pathogenic on onion, because stock seed imported into this region originates in many different countries. Research is needed to assess the genetic variation of populations of $B$. aclada and $B$. allii prevalent on onion bulb and seed crops in Washington.

Neck rot continues to cause losses to the onion industry in Washington and other regions of the world. Increasingly, infected seed is suspected as the primary cause of epidemics of neck rot, raising concern in regions of seed production such as the Pacific Northwest. Despite the ubiquitous and latent nature of $B$. allii detected in seed crops in the Columbia Basin in this study, the lack of evidence of systemic movement of the pathogen from stock seed and into harvested seed suggests seedborne inoculum may be less important in the epidemiology of this pathogen in semi-arid regions than alternative sources of inoculum. Nonetheless, in regions with conditions more favorable than those of the Columbia Basin for neck rot and scape blight, planting Botrytis-free onion seed would be the first step toward effective reduction in losses.

\section{ACKNOWLEDGMENTS}

We thank the Columbia Basin Vegetable Seed Association and the Washington State Commission for Pesticide Registration for funding this research; seed companies for providing access to onion seed crops as well as stock or harvested seed samples; and S. Sampson, K. Berglund, K. Brooks, S. Lloyd, and K. Baber for field and lab assistance. This research was supported by the Agricultural Research Center of Washington State University and assigned Plant Pathology New Series No. 0377.

\section{LITERATURE CITED}

1. Blodgett, E. C. 1946. Observations on blasting of onion seed heads in Idaho. Plant Dis. Rep. 30:77-81

2. Chilvers, M. I. 2003. Epidemiology of Botrytis spp. associated with neck rot of onion in northern Tasmania. Ph.D. dissertation. University of Tasmania, Australia.

3. Clark, C. A., and Lorbeer, J. W. 1973. Symptomatology, etiology, and histopathology of Botrytis brown stain of onion. Phytopathology 63:1231-1235.

4. Crowe, F. J., Mohan, S. K., and Schwartz, H F. 1995. Other Botrytis diseases. Pages 19-20, In: Compendium of Onion and Garlic Diseases. H. F. Schwartz and S. K. Mohan, editors. American Phytopathological Society Press, St. Paul, MN.

5. Dana, B. F. 1923. Botrytis diseases in Washington. (Abstr.) Phytopathology 13:509.

6. du Toit, L. J., Derie, M. L., Hsiang, T., and Pelter, G. Q. 2002. Botrytis porri in onion seed crops and onion seed. Plant Dis. 86:1178.

7. du Toit, L. J., Derie, M. L., and Pelter, G. Q. 2002. Botrytis species associated with onion seed crops in Washington State. Pages 47-56 In: Proc. 2002 Nat. Allium Res. Conf. Pasco, WA.

8. Ellerbrock, L. A., and Lorbeer, J. W. 1977. Etiology and control of onion flower blight. Phytopathology 67:155-159.

9. Fresenius, G. 1850. Beiträge zur Mykologie. Frankfurt am Main, Germany.

10. Hancock, J. G., and Lorbeer, J. W. 1963. Pathogenesis of Botrytis cinerea, B. squamosa, and $B$. allii on onion leaves. Phytopathology 53:669-673.

11. Heald, F. D., and Dana, B. F. 1924. Notes on plant disease in Washington. I. Botrytis diseases. Trans. Am. Microsc. Soc. 43:136-144.

12. Hennebert, G. L. 1963. Les Botrytis des Allium. Meded. Landbouwhoogessch. Opzoekingsstn. Staat Gent. 28:851-876.

13. Hennebert, G. L. 1973. Botrytis and Botrytislike genera. Persoonia 7:183-204.

14. Hinman, H., and Pelter, G. Q. 1997. Farm Business Management Reports: 1997 Enterprise Budgets, Carrot Seed, Radish Seed, and Onion Seed, Columbia Basin, Washington. Wash. State Univ. Coop. Ext. Bull. 1664.

15. Kritzman, G. 1983. Studies on the fungicidal control of bulb rot caused by Botrytis allii in onions for the production of seeds. J. Agric. Sci. 100:519-525. 
16. Kritzman, G., and Netzer, D. 1978. A selective medium for isolation and identification of $\mathrm{Bo}$ trytis spp. from soil and seed. Phytoparasitica 6:3-7.

17. Lacy, M. L., and Lorbeer, J. W. 1995. Botrytis neck rot. Pages 18-19 in: Compendium of Onion and Garlic Diseases. H. F. Schwartz and S. K. Mohan, editors. American Phytopathological Society Press, St. Paul, MN

18. Linfield, C. A., Kenny, S. R., and Lyons, N. F. 1995. A serological test for detecting Botrytis allii, the cause of neck rot of onion bulbs. Ann. Appl. Biol. 126:259-268.

19. Maude, R. B. 1983. The correlation between seed-borne infection by Botrytis allii and neck rot development in store. Seed Sci. Technol. 11:829-834.

20. Maude, R. B., Bambridge, J. M., and Presly, A. H. 1982. The persistence of Botrytis allii in field soil. Plant Pathol. 31:247-252.

21. Maude, R. B., and Presly, A. H. 1977. Neck rot (Botrytis allii) of bulb onions. I. Seed-borne infection and its relationship to the disease in the onion crop. Ann. Appl. Biol. 86:163-180.

22. Maude, R. B., and Presly, A. H. 1977. Neck rot (Botrytis allii) of bulb onions. II. Seed-borne infection in relationship to the disease in store and the effect of seed treatment. Ann. Appl. Biol. 86:181-188.

23. Metcalf, D. 1998. Botrytis seed testing-What the results mean? Onions Australia 15:33-34.

24. Mohan, S. L., and Schwartz, H. F. 2000. Common Names of Plant Diseases: Diseases of Onion (Allium cepa L.). American Phytopathological Society, St. Paul, MN. Published online.

25. Munn, M. T. 1917. Neck rot disease of onions.
N. Y. Agric. Exp. Stn. Geneva Tech. Bull. 437:363-455

26. Owen, J. H., Walker, J. C., and Stahmann, M. A. 1950. Variability in neck-rot fungi. Phytopathology 40:749-768.

27. Netzer, D., and Dishon, I. 1966. Occurrence of Botrytis allii in onions for seed production in Israel. Plant Dis. Rep. 50:21.

28. Nielsen, K., Justesen, A. F., Funck Jensen, D., and Yohalem, D. S. 2001. Universally primed polymerase chain reaction alleles and internal transcribed spacer restriction fragment length polymorphisms distinguish two subgroups in Botrytis aclada distinct from $B$. byssoidea. Phytopathology 91:527-533.

29. Nielsen, K., and Yohalem, D. S. 2001. Origin of a polyploid Botrytis pathogen through interspecific hybridization between Botrytis aclada and B. byssoidea. Mycologia 93:264-271.

30. Nielsen, K., and Yohalem, D. S. 2002. PCR detection and RFLP differentiation of Botrytis species associated with neck rot of onion. Plant Dis. 86:682-686.

31. Pelter, G. Q. 2001. A Recent History of Columbia Basin Vegetable Seed Acreage: 19912000. Wash. State Univ. Coop. Ext. GrantAdams Area.

32. Presly, A. H. 1985. Studies on Botrytis spp. occurring on onions (Allium cepa) and leeks (Allium porrum). Plant Pathol. 34:422-427.

33. Presly, A. H. 1985. Methods for inducing sporulation of some Botrytis species occurring on onions and leeks. Trans. Br. Mycol. Soc. 85:621-624.

34. Ramsey, G. R., and Lorbeer, J. W. 1986. Flower blight and scape girdling on onion grown for seed production in New York. Phy- topathology 76:599-603.

35. Ramsey, G. R., and Lorbeer, J. W. 1986 Pathogenicity of Botrytis species on onion umbels and scapes under controlled conditions. Phytopathology 76:604-612.

36. Ramsey, G. R., and Lorbeer, J. W. 1986. The role of temperature and free moisture in onion flower blight. Phytopathology 76:612-616.

37. Schreiber, A., and Ritchie, L. 1995. Washington Minor Crops. Food \& Environmental Quality Lab, Washington State University Tri Cities, Richland, WA.

38. Shirane, N., Masuko, M., and Hayashi, Y 1989. Light microscopic observations of nuclei and mitotic chromosomes of Botrytis species. Phytopathology 79:728-730.

39. Thomas, J., Schreiber, A., Pelter, G. Q., and Havens, D. 1997. Washington's Small-Seeded Vegetable Seed Industry. Wash. State Univ. Ext. Bull. No. 1829

40. Tichelaar, G. M. 1967. Studies on the biology of Botrytis allii on Allium cepa. Neth. J. Plan Pathol. 73:157-160.

41. Tylkowska, K., and Dorna, H. 2001. Onion (Allium cepa) seed and plant health with special reference to Botrytis allii. Phytopathol. Pol. 21:55-68.

42. Walker, J. C. 1925. Two undescribed species of Botrytis associated with the neck rot disease of onion bulbs. Phytopathology 15:708-713.

43. Yarwood, C. E. 1938. Botrytis infection on onion leaves and seed stalks. Seed Sci. Technol. 22:428-429.

44. Yohalem, D. S., Nielsen, K., and Nicolaisen, M. 2003. Taxonomic and nomenclatural clarification of the onion neck rotting Botrytis species. Mycotaxon 85:175-182. 